\title{
Overall justice, work group identification and work outcomes: test of moderated mediation process
}

Article

Accepted Version

Creative Commons: Attribution-Noncommercial-No Derivative Works 4.0

Patel, C., Budhwar, P. S. and Varma, A. (2012) Overall justice, work group identification and work outcomes: test of moderated mediation process. Journal of World Business, 47 (2). pp. 213-222. ISSN 1090-9516 doi:

https://doi.org/10.1016/j.jwb.2011.04.008 Available at https://centaur.reading.ac.uk/68843/

It is advisable to refer to the publisher's version if you intend to cite from the work. See Guidance on citing.

To link to this article DOI: http://dx.doi.org/10.1016/j.jwb.2011.04.008

Publisher: Elsevier

All outputs in CentAUR are protected by Intellectual Property Rights law, including copyright law. Copyright and IPR is retained by the creators or other copyright holders. Terms and conditions for use of this material are defined in the End User Agreement.

www.reading.ac.uk/centaur 
Central Archive at the University of Reading

Reading's research outputs online 
Overall justice, work group identification and work outcomes: Test of moderated mediation process

Charmi Patel $^{\mathrm{a}, *}$, Pawan Budhwar ${ }^{\mathrm{a}, 1}$, Arup Varma ${ }^{\mathrm{b}, 2}$

${ }^{a}$ Work and Organisational Psychology Group, Aston Business School, Aston University, Birmingham B4 7ET, UK

${ }^{\mathrm{b}}$ Institute of Human Resources \& Employment Relations, Loyola University Chicago, 1 East Pearson Street, \#406, Chicago, IL 6061 1, USA 
Keywords:

Overall justice Indian Call Centres

Group engagement model Presenteeism

Moderated mediation 
Abstract

This study examined an integrated model of the antecedents and outcomes of organisational and overall justice using a sample of Indian Call Centre employees ( $\mathrm{n}=$ 458). Results of structural equation modelling (SEM) revealed that the four organisational justice dimensions relate to overall justice. Further, work group identification mediated the influence of overall justice on counterproductive work behaviors, such as presenteeism and social loafing, while conscientiousness was a significant moderator between work group identification and presenteeism and social loafing. Theoretical and practical implications are discussed. 
An organisation's sustainable competitive advantage is depen-dent on the proactive behaviors of its members (Kanter, 1983; Katz \& Kahn, 1978). It is critical that we study employees' positive work attitudes and extra-role contributions, so we may better under-stand and explain the motivational basis of such actions and behaviors. The employment relationship may be characterized either as a social or economic exchange. (Blau, 1964, pp. 91-92) described social exchange as 'the voluntary actions of individuals that are motivated by the returns they are expected to bring and typically do in fact bring from others'. Social exchange, as an employment relationship, may be initiated by an organisation's fair treatment of its employees. This favor 'or spontaneous gesture of goodwill on the part of the organisation (or its agents) engenders an obligation on the part of employees to reciprocate the good deeds of the organisation'. Consequently, much research has examined the relationship between an organisation's fair treat-ment of its employees or organisational justice and work attitudes and behaviors (Aryee, Budhwar, \& Chen, 2002; Colquitt, Conlon, Wesson, Porter, \& Ng, 2001; Cropanzano \& Greenberg, 1997; Moon, Mayer, Kamdar, \& Takeuchi, 2008; Moorman, Niehoff, \& Organ, 1993; Konovsky \& Pugh, 1994). 
Although this stream of research has contributed substantially to explicating the social exchange basis of employee attitudes and behaviors, it is not without limitations. First, in spite of the tripartite conceptualization of organisational justice, much of this research has not examined all three dimensions of justice simultaneously (Manogran, Stauffer, \& Conlon, 1994). For example, Masterson, Lewis, Goldman, and Taylor (2000) examined proce-dural and interactional justice while Moorman et al. (1993) examined procedural justice. On the other hand Moon et al. (2008) examined procedural and distributive justice but did not take into account interactional or informational justice dimensions in their study. While Aryee et al. (2002) did look into the three dimensions of organisational justice, their study overlooked the importance of the informational justice dimension in predicting work outcomes.

Adopting a multi-foci perspective (the view that employees differentiate between the treatment they receive from various bodies in the workplace such as the organisation, co-workers and supervisors), organisational justice research has shown that these various justice dimensions relate to relevant work outcomes differently (Aryee et al., 2002; Walumbwa, Corpanzano, \& Hartnell, 2009). There is a growing concern that the focus on specific dimensions of the construct does not reflect the depth and richness of the totality of individual's experience of organisational justice (Greenberg, 2001; Lind, 2001; Shapiro, 2001).

Finally, much of this stream of research has been conducted primarily in the individualist cultures of the West (particularly the U.S. and Europe) raising questions about the extent to which the findings are generalizable to the collectivist cultures of the East (see, e.g., Hofstede, 1980). According to Tripathi (1990), Indian society is characterized by meaningful ties among people and an importance on values such as respect 

dependency and social obligation. Similarly, Parikh and Garg (1990) observed that in India's collectivist culture, each individual has a distinctive role, and relatedness is defined by bonds of caste, community and neighbour. Therefore, "an examination of the emergence and functioning of social exchange processes in collectivist Eastern cultures where values differ dramatically from those typically found in a Western context, should enhance our understanding of the motivational underpinnings of employee work attitudes and behaviors in a competitive globalized econo-my"' (Aryee et al., 2002, p. 268).

Some studies have addressed the problems faced by employees in the BPO (Business Process Outsourcing) sector more specifically within call centres. For example, Rubery, Carroll, Cooke, Grugulis, and Earnshaw (2004) highlight employment issues and employ-ment relations in the context of a UK based call centre. Witt, Andrews, and Carlson (2004) report the interaction between emotional exhaustion and conscientiousness and their effect on performance of customer service representatives (CSRs) in U.S. call centres. Similarly, Lewig and Dollard (2003) observe issues related to emotional dissonance, emotional exhaustion and job satisfac-tion in call centre workers. They found along similar lines, Grebner et al. (2003) have looked at working conditions, well-being and job related issues of agents in the call centre industry. Some studies have also looked into issues related to stress and satisfaction on employee performance and retention in the outsourcing firms, and their impact on empowerment and organisational commitment (e.g., Batt \& Appelbaum, 1995; Grimshaw \& Rubery, 1998; Knights \& McCabe, 1998; Taylor, Mulvey, Hyman, \& Bain 2002; Mulholland, 2004; Rose \& Wright, 2005). However, none of these studies look at social exchange relationships to predict work attitudes and outcomes within the general call centres context or specifically within the Indian Call Centre context.

The present study contributes to the overall justice literature by pursuing two objectives. Following from the group engagement model and social identity theory prediction that individuals rely on their various justice experience to form overall justice perceptions, our first objective is to examine the perceptions of organisational justice as antecedents of overall justice (Tyler \& Blader, 2003). Our second objective is to examine work group identification as a form of organisational attitude resulting from perceptions of overall justice and conscientiousness (personality trait) as complementary mod-erators of the influence of overall justice on counterproductive work behaviors such as presenteeism and social loafing. By examining the underlying mechanisms that affect the overall justice and work outcomes relationships, we seek to move research to fully understand the social exchange basis of employee work attitudes and behaviors by simultaneously examining all four dimensions (procedural, distributive, informational and interactional) of orga-nisational justice to predict overall justice perception. Understand-ing mechanisms through which overall fairness perception impacts its underlying outcomes will provide practical knowledge for organisations to enhance employee experience of fairness at workplace and resulting beneficial outcomes for both individuals and organisations.

\section{Theoretical framework and hypotheses development}

Most research on justice identifies four distinct types of justice: procedural, distributive, informational and interactional (Colquitt, 2001; Colquitt et al., 2001). Indeed, empirical support exists for each of these conceptualisations, and has established the relationship between each type of justice and a broad range of individuals' attitudes and behaviors (see for, e.g., Cropanzano, Byrne, Bobocel, \& Rupp, 2001; Konovsky, 2000). Several research-ers have questioned the benefits of focusing exclusively on specific types of justice. They suggest a shift toward examining overall 
justice judgments (Ambrose \& Arnaud, 2005; Lind, 2001; Shapiro, 2001). In this connection, Greenberg (2001) has argued that when individuals form impressions of justice, they are making a holistic judgment. Similarly, Lind (2001) noted that although individuals can distinguish between the sources of their justice experience when asked, what drives behaviors is an overall sense of fairness. Finally, Tornblom and Vermunt (1999) argued that individuals consider fairness as a whole than sum of its parts and that the components of fairness "are meaningful only in relation to the overall fairness of the situation" (p. 51). The common thread running through all of this research is that limited focus on distinct forms of justice may not provide either a complete or an accurate picture of how individuals make and use justice judgments.

Borrowing the lens from group engagement model and social identity theory, we posit that individual's behavioral effort on behalf of a collective to which he or she belongs (which we will broadly refer to as their work group) is influenced by the role the group plays in how the individual thinks and feels about themselves (i.e., by the social identity they form around the group; Tajfel \& Turner, 1979). Social identity is affected by the processes and treatment that people encounter in their work groups (i.e., their experience with how the group functions), which in turn impacts their experience as group members. Research has shown that fairness is a primary dimension that people use to evaluate the processes and treatment they encounter in their groups (Tyler, 1999; Tyler \& Blader, 2000). We also posit that work group identification will relate to counterproductive work behaviors such as presenteeism and social loafing, moderated by conscientiousness. From a social exchange perspective, this means that the lack of fair treatment employees receive from their organisations will lead them to engage in counterproductive work behaviors such as presenteeism and social loafing.

\subsection{Organisational justice and overall justice}

Overall justice perceptions represent global evaluations of the fairness of an entity based on personal experiences as well as on the experiences of others (Ambrose \& Schminke, 2009). Increasingly, scholars have suggested that specific justice dimensions combine to shape overall justice perceptions (e.g., Ambrose \& Arnaud, 2005; Ambrose \& Schminke, 2009; Lind, 2001; Lind \& Tyler, 1988; Lipponen, Olkkonen, \& Moilanen, 2004; Tornblom \& Vermunt, 1999). However, these relationships have been examined in only a few studies and the results have been mixed. Kim and Leung (2007) found that distributive justice, interactional justice, and procedural justices were the strongest predictors of overall justice, respectively (but effects varied across cultures). In their Study 1, Ambrose and Schminke (2009) found that procedural, distributive, and interac-tional justice were the strongest predictors of overall justice, respectively. However, in a second study, Ambrose and Schminke (2009) found thatonlyprocedural andinteractional justice explained significant variance in overall justice perceptions. Similarly, Jones and Martens (2007) found that interpersonal, informational, and distributive justice were the strongest predictors of overall justice, respectively, though procedural justice did not explain unique variance in overall justice perceptions. As such, we predict:

Hypothesis 1. All four dimensions of organisational justice, i.e., procedural, distributive, informational and interactional, will pos-itively relate to overall justice.

\subsection{Justice and work group identification}

Researchers have argued that organisational justice is a significant predictor of organisational identification because perception of justice shapes the thoughts, feelings, and actions 

of individuals and provides them with ways of evaluating social situations (Pratt, 1998; Tyler \& Smith, 1997; Tyler, 1999). For example, procedural justice and distributive justice have been found to be positively related to organisational identification (Olkkonen \& Lipponen, 2006), and procedural justice is reported to be positively related to post-merger organisational identification.

One of the key theoretical bases for understanding organisational identification is social identity theory, 'people use groups as sources of information about themselves' (Tyler, Degoey, \& Smith, 1996, p. 914) and individuals may use their status or social standing in their organisations to enhance their self-worth (Tyler, 1999). Past studies have applied the social identity theory to explain the effects of organisational identification on job satisfaction, turnover intentions, and organisational citizenship behavior (Dick, Wagner, Stellmacher, \& Christ, 2004; Van Knippenberg \& Sleebos, 2006).

Relatedly, Tyler and Blader (2003) have proposed the group engagement model which explains co-operation in groups in terms of group identification, and draws together the insights of the group-value model of procedural justice (Lind, Kanfer, \& Earley, 1990) and the relational model of authority (Tyler \& Caine, 1981) and extends them to understand the antecedents of cooperation in groups (Tyler \& Blader, 2000). The group engagement model sheds light on our understanding of what people are seeking when they involve themselves in groups and the importance of justice in social settings. As one might expect, people have considerable discretion about the degree to which they invest themselves in their groups by working on behalf of the group. To examine this issue, the group engagement model distinguishes between two classes of co-operative behavior: mandatory behavior and discretionary behavior. Mandatory behavior is stipulated by the group whereas discretionary behavior originates within the group member (Tyler \& Blader, 2003). The model also argues that each of these forms of behaviors is differently motivated. Mandatory behaviors are more strongly affected by incentives and sanctions whereas discretionary behaviors are more strongly under the influence of people's internal motivations, e.g., their attitudes, values, etc. (Tyler \& Blader, 2003).

The group engagement model further distinguishes between three aspects of group-linked or social identity: identification, pride and respect. Identification reflects that degree to which people cognitively merge their sense of self and their evaluations of self-worth with their judgments of the characteristics and status of their groups. Pride reflects the person's evaluation of the status of their group. Respect reflects their evaluation of their status within the group. The group engagement model argues that each of these aspects of identity play an important role in people's relationship to their group. Thus, the group engagement model hypothesises that when people identify more strongly with a group, they will be more willing to act co-operatively in that group-investing their time and energy in working to see the group succeed (Tyler \& Blader, 2003).

Research has suggested the premise of group engagement model by showing that identification; pride and respect are connected to feelings of self-esteem and self-worth. This is consistent with the argument of the group engagement model that people use group identity based judgments to evaluate themselves (Tyler \& Blader, 2003). Thus, all the three identity elements of the group engagement model are predicted to be related to engagement in the groups. The overall group engagement model makes clear why people focus so heavily on whether or not their groups' procedures are fair. The procedural fairness judgment provides key information that shapes the degree to which people regard their group as having high status, regard themselves as having high status in their group and identify with the group by merging their sense of self with the group. Procedural justice judgments are thus a key antecedent of identity assessments (Tyler \& Blader, 2003). 
It should be noted that some researchers have suggested that distributive justice, procedural justice, informational justice and interactional justice are distinct constructs (Colquitt et al., 2001). Not surprisingly, previous studies on organisational justice have focused largely on distributive and procedural justice (Cohen-Charash \& Spector, 2001;Loi, Ngo, \& Foley, 2006). Nevertheless, researchers have turned their attention away from a focus on the fairness of reward allocations to interpersonal treatment on work procedures (for example, Colquitt, 2001; Roch \& Shanock, 2006) because an individual's feelings about organisational fairness may not be fully explained by distributive or procedural justice. Therefore, distributive and procedural justice is increasingly replaced by informational justice and interactional justice in the investigation of the social exchange relationship between employ-ees and organisations. The inclusion of informational and interper-sonal justice adds significant values to research of organisational behavior because the provision of reasonable explanation - that is, informational justice - gives clues to employees about the activities of an organisation and the opportunities for their personal growth (Rousseau, 1998), while the fairness of interactional justice is about employees' status within their organisation (Blader \& Tyler, 2009; Eblen, 1987; Holtz \& Harold, 2009; Leifer \& Maslach, 1988).

Consistent with this line of reasoning, recent research has indicated that overall justice predicts employees' overall job satisfaction better than specific justice dimensions (Ambrose \& Schminke, 2009; Jones \& Martens, 2007). Additionally, focusing on overall justice can provide a more complete picture of how justice influences other organisational phenomena (Ambrose \& Arnaud, 2005; Colquitt, Greenberg, \& Scott, 2005). As such, we predict:

Hypothesis 2. Overall justice will positively relate to work group identification.

\subsection{Presenteeism and social loafing}

An organisation's long-term viability is critically dependenton the positive behaviors of its members (Kanter, 1983; Katz \& Kahn, 1978). It is not surprising that recent years have seen an explosion of interest among organisational researchers in counterproductive work behaviors (CWB), which consists of intentional acts by employees that harm organisations or their stakeholders. This study, therefore, looks at two such CWB behaviors; presenteeism and social loafing. Though there is a wealth of literature available on social loafing, there is a paucity of research on presenteeism. Most of the literature on presenteeism is within the medical field, where presenteeism is defined mainly as a work culture which results in loss of productivity as employees go to work sick or tired (Hemp, 2004; Zengerle, 2004; Ceridian, 2006; Goetzel et al., 2004). Presenteeism is regarded generally as the opposite of absenteeism, i.e., simply the practice of coming toworkwhen an individual should not,which results in being physically present but functionally absent.

Aronsson, Gustafsson, \& Dallner (2000) identified a number of possible factors that might be responsible for presenteeism in a study which involved different occupational categories. Jobs that provide services to people were more prone to sickness presenteeism than other occupations, because of a felt responsi-bility toward clients. People working in occupations where clients depend on them and where there is no one to replace them may be more likely to come to work sick rather than to stay away (Aronsson et al., 2000). Further, employees might be more likely to spend more time at work while ill, due to increases in job insecurity and in workplace demands (Lewis \& Cooper, 1999). Increasingly, employees may feel afraid to stay away from work (Lewis \& Cooper, 1996;Simpson, 1998), feeling the need to put in long hours (Worrall \& Cooper, 2002) due to insecurities related to 
job loss. As we note above, much of the research on presenteeism appears in the medical literature (Aronsson et al., 2000; Berger, Howell, Nicholson \& Sharda, 2003; Goetzel et al., 2004; Koopman et al., 2002; Stewart, Ricci, Chee, Morganstein, \& Lipton, 2003; Wang et al., 2003). However, the root causes of presenteeism are not always medical. Loss of productivity or lower productivity issues may also arise due to other problems, e.g., financial trouble, work-life imbalance, etc., negative perception of work environ-ment, including conflict with supervisor or colleague or the perception of unfairness in the workplace.

Another crucial concept related to CWB is 'social loafing', i.e., "the tendency of individuals to reduce effort when they are working in groups" (Latane, Williams\& Harkins, 1979). The main explanation of social loafing is the tendency for an individual's effort to decrease when people work in groups rather than individually. Loafing has been shown to occur for a wide variety of tasks (Latane et al., 1979; Earley, 1989). In addition to group performance, social loafing has been associated with a number of negative outcomes. For example, Duffy and Shaw (2000) showed that social loafing was negatively related to group cohesiveness and potency which in turn, were related to performance, absenteeism, and group satisfaction. Kidwell and Bennett (1993) identified rational choice, normative conformity, and affective bonding as alternative motives for engaging in social loafing. Researchers such as Gagne and Zuckerman (1999) found that identifiably of individual contributions; task visibility (George, 1992); potential for evaluation of individual contributions (Karau \& Williams, 1994); and incentives for high performance (George, 1995; Miles \& Greenberg, 1993) were all negatively related to social loafing. In this connection, it should be pointed out that loafing occurs, or is strengthened, in the absence of an individual evaluation structure imposed by the environment (Price \& Harrison, 2006). This occurs because working in the group environment results in less self-awareness (Mullen, 1983). Several studies have shown that the ability for an individual to participate in social loafing increases as the group size increases. If groups remain small, the individual will not have the opportunity to become invisible and their lack of input will be readily evident. The lack of identifiably in a group is a psychological production that has been documented in several studies (Carron, Burke, \& Prapavessis, 2004). Thus, a social loafer is not productive and, as such, this also reflects a kind of presenteeism as the employee is on the job but not fully productive. Therefore, it is imperative to study the causes of both social loafing and presenteeism, as these are counterpro-ductive work behaviors which have possible detrimental effects on the overall functioning of any organisation.

Studies of organisational justice have previously demonstrated that perceived fairness of rewards, organisational procedures, and interpersonal treatment are related to individual attitudes and behaviors (Aryee et al., 2002; Holtz \& Harold, 2009; Moon et al., 2008). Furthermore, the extent to which individuals perceive justice in the organisation was related to positive outcomes such as job satisfaction, organisational commitment, performance and organi-sational citizenship behavior (Aryee et al., 2002; Colquitt et al., 2001; Erdogan \& Liden, 2006). Previous studies have also indicated that individuals who identify with their organisations to some extent may have a higher level of job satisfaction (Van Knippenberg \& Van Schie, 2000; Van Knippenberg and Sleebos, 2001), in-role and extra-role performance (Tyler \& Blader, 2000; Tyler and Blader, 2001), effective inter-group relations (Richter, West, Van Dick, \& Dawson, 2006) and lower level of turnover intentions (Abrams, Ando, \& Hinkle, 1998). Further, Greenberg (1990) and Skarlicki, Folger and colleagues (Fox, Spector, \& Miles, 2001; Skarlicki \& Folger, 1997; Skarlicki, Folger, \& Tesluk, 1999) have all taken an organisational justice perspective, viewing CWB as a cognition-based response to experienced injustice at workplace. 
Indeed, recent research has shown that the relationship between justice perceptions and individual behaviors is mediated by social exchange relationships (Masterson et al., 2000; Murphy, Wayne, Liden, \& Erdogan, 2003). As such, we predict:

Hypothesis 3a. Work group identification will mediate the influence of overall justice on presenteeism.

Hypothesis $3 \mathrm{~b}$. Work group identification will mediate the influ-ence of overall justice on social loafing.

\subsection{Personality and work outcomes}

The resurgence of interest in personality at work began in the early 1980s. Since then, a wide range of individual studies have been conducted to reveal links between personality, work attitudes and work performance (e.g., Moon et al., 2008; Robertson \& Callinan, 1998; Nikolau \& Robertson, 2001). Over the past decade, the conceptualization of personality as comprising five broad factors (i.e., the five factor model (FFM), comprising neuroticism, extraversion, and openness to experience, agreeable-ness, and conscientiousness) has dominated the literature, studying how an individual's personality might be related to organisational outcomes. Meta-analyses (Hough, Eaton, Dunnette, Kemp, \& McCloy, 1990) have demonstrated consistent relation-ships between the broad factors of personality and a wide range of organisational outcomes. The effectiveness of the big five taxonomy of personality, especially the construct of conscien-tiousness, in predicting individual performance has been consis-tently demonstrated (Barrick \& Mount, 1991). The personality trait of conscientiousness is characterized by planning, thoroughness, hard work, and purposeful striving toward goals (Digman, 1990). In a study exploring the relationship between personality, job satisfaction and OCB (organisation citizenship behavior) Organ and Lingl (1995) results showed that it was only conscientiousness that showed a reliable connection in predicting OCB. In a meta-analysis published the same year Organ and Ryan (1995) reported that the big five personality trait of conscientiousness was specifically related to one aspect of OCB, impersonal or generalized compli-ance. As well as being a predictor of generalized compliance, conscientiousness also accounted for unique variance in three dimensions of OCB - compliance, altruism, and civic virtue (Konovosky and Organ, 1996).

Barrick, Stewart, Neubert, and Mount (1998) reported that work teams with higher mean levels of conscientiousness, agreeableness, extraversion, and emotional stability had higher supervisor ratings of team performance. The construct of conscientiousness includes feelings of competence, achievement striving, self-discipline, and dutifulness (Costa, McCrae, \& Dye, 1991). Teams made up of members who are conscientious are more deliberate, organised, and task focused, which should be related to effective team performance. In this connection, research has shown a relationship between achievement motiva-tion (a component of conscientiousness) and group performance (Schneider \& Delaney, 1972). Similarly, conscientiousness has been shown to have a positive relationship to job performance. Indeed, it is shown to predict job performance better than cognitive ability tests on overall performance, including low complexity jobs in which cognitive ability tests have been shown to be poor predictors of performance (Avis, Kudisch, \& Fortunato, 2002). Conscientiousness is proposed as a moderator between work group identification, presenteeism and social loafing. As such, we predict:

Hypothesis 4a. Conscientiousness will influence the interaction between work group identification on presenteeism. 
Hypothesis 4b. Conscientiousness will influence the interaction between work group identification on social loafing.

\section{Method}

Respondents were employees and their team leaders, drawn from 5 major call centre firms located at Mindspace, in Mumbai (India). The employees were all from the billing department, handling billing related queries, working at the same level of the organisational hierarchy. All participants were informed that their participation was voluntary and confidential. Additionally, all employees were provided self-addressed stamped envelopes in which to return their responses in confidential manner. The survey was administered during company working hours.

The average age of participants was $24.61(\mathrm{~s} . \mathrm{d} .=6.20)$ and $52 \%$ were males. They had a mean of 15.42 years of education $(\mathrm{s} . \mathrm{d} .=3.84)$ and a mean organisational tenure of 1.57 years $($ s.d. $=3.07)$, with a mean team leader-subordinate tenure of 1.05 years $(\mathrm{s} . \mathrm{d} .=3.63)$. The average age of team leaders was 32.12 (s.d. $=5.61)$ and $60 \%$ were males. They had a mean of 16.05 years of education $($ s.d. $=2.33)$ and a mean organisational tenure of 4.18 (s.d. $=4.55)$.

Out of the 800 questionnaires distributed, 473 completed and usable questionnaires were returned and 458 were usable. We were unable to match responses of the other 15 subordinates and those of their team leaders. On average, a team leader rated at least 3 subordinates (ranging from 3 to maximum 5).

\subsection{Measures}

Organisational justice: This scale was adapted from Colquitt's (2001) 20 item measure that asked participants to give their responses on a 5point Likert scale where $1=$ to a small extent and 2 = very large extent. Next, the Thibaut and Walker (1975) items were used to measure procedural justice. To measure distributive justice, we used the items from the Leventhal (1976) scale. Finally, Bies and Moag's (1986) items were used to measure both interpersonal justice and informational justice.

Overall organisational justice: Employee perceptions of justice were assessed with the six-item scale developed and validated by Ambrose and Schminke (2009), while overall supervisory justice perceptions were assessed with the same six item scale, altered slightly to change the focus of the fairness to be one's supervisor rather than one's organisation.

Work group identification: This scale was adapted from Mael \& Ashforth's (1992) 6-item measure that asked participants to give their ratings on a 5 point Likert scale where $1=$ strongly agree to $5=$ strongly disagree.

Conscientiousness: This measure was obtained from the Oregon Research Institute sponsored website called International Person-ality Item Pool (2001). The questions in the survey were randomly organised since they were positively and negatively keyed; meaning that some questions were targeted at measuring high 
levels of conscientiousness and others to low levels of conscien-tiousness. The scoring of the same consisted of reverse scoring the negatively keyed questions and then averaging all the scores to find a single number measure.

Presenteeism: This scale was adapted from 6-item Stanford Presenteeism Scale (2001) version, drawn from Koopman et al. (2002). The selfreport items were tailored in order for team leaders to rate the subordinates. The 'I' was replaced with 'their/ them'. Team leaders were asked to describe their subordinates work behaviors during the month prior to the survey administra-tion. For each of the statements they were asked to check any one out of the 5 responses $(1=$ strongly disagree to $5=$ strongly agree $)$ which showed agreement or disagreement with the statement.

Social loafing: This scale was adapted from George's (1992) 10-item measure that asked team leaders to give their responses on a 5 point scale ranging from $1=$ not at all characteristic to $5=$ very characteristic.

\subsection{Data analysis}

Structural equation modelling (SEM) was used to test the measurement model. AMOS (version 5.0) and HLM were used in order to test the hypotheses and establish good model fit Fornell and Larcher (1981). It should be noted that the Baron and Kenny (1986) mediation analysis was not found suitable due to the complexity of the model (i.e., moderated mediation) under consideration and limitations with the method. In this connection, James and Brett (1984) coined the term moderated mediation, suggesting it for mediation models involving relations that "require the addition of a moderator for either the $\mathrm{m}^{\wedge}=\mathrm{f}(\mathrm{x})$ or $\mathrm{y}^{\wedge}=\mathrm{f}(\mathrm{m})$ relations, or both" (p. 314). Moderated mediation models attempt to explain both how and when a given effect occurs (Frone, 1999). Moderated mediation occurs when the strength of an indirect effect depends on the level of some variable. That is, when mediation relations are contingent on the level of a moderator Edwards and Lambert (2007). There are multiple ways in which the magnitude of an indirect effect may be dependent upon a moderator. We use Preacher, Rucker, and Hayes (2007) specific suggestions to measure moderated mediation effects, which are referred to as models 1-5. Using the syntax for the macro described by Preacher et al. (2007), analyses correspond-ing to model 3 described were conducted in SPSS. The SEM approach further allowed us to test all relationships at once to account for any potential measurement error as opposed to testing the model in a piecemeal fashion. Also, because individuals are nested within groups, we deemed it important to analyze our data using random coefficient modelling (commonly referred to as hierarchical linear modelling HLM).

\section{Results}

We conducted a series of confirmatory factor analyses to examine whether the dimensions of organisational justice: procedural, distributive, informational, interactional, overall justice, work group identification and conscientiousness, all of 
Table 1

Comparisons of measurement models.

\begin{tabular}{|c|c|c|c|c|c|c|c|}
\hline Models and structure & $\mathrm{X}^{2}$ & $\mathrm{df}$ & $\mathrm{Dx}^{2}$ & TLI & CFI & RMR & RMSEA \\
\hline 7 factors (PJ, DJ, IJ, InJ, OJ, WGI, Con) & 266.34 & 87 & & 0.97 & 0.96 & 0.02 & 0.03 \\
\hline 6 factors (IJ and InJ merged, PJ, DJ, OJ, WGI, Con) & 551.66 & 91 & 213.89 & 0.85 & 0.89 & 0.04 & 0.08 \\
\hline 5 factors (PJ, DJ and OJ merged, IJ, InJ, WGI, Con) & 355.8 & 94 & 117.76 & 0.91 & 0.93 & 0.03 & 0.08 \\
\hline 4 factors (PJ, DJ, IJ and InJ merged, OJ, WGI, Con) & 606.09 & 98 & 322.52 & 0.82 & 0.88 & 0.04 & 0.08 \\
\hline 1 factor (PJ, DJ, IJ, InJ, OJ, WGI, Con all merged) & 1246.34 & 105 & 1601.69 & 0.67 & 0.69 & 0.08 & 0.21 \\
\hline
\end{tabular}

Note: $\mathrm{n}=458$. $\mathrm{PJ}=$ procedural justice, $\mathrm{DJ}=$ distributive justice, $\mathrm{IJ}=$ informational justice, $\mathrm{InJ}=$ interactional justice, $\mathrm{OJ}=$ overall justice, $\mathrm{WGI}=$ work group identification, and Con $=$ conscientiousness.

$* *$ Significant at $\mathrm{p}<0.001$. 
Table 2

Means, standard deviations and correlations among study variables.

\begin{tabular}{|c|c|c|c|c|c|c|c|c|c|c|c|}
\hline Variables & M & $\mathrm{SD}$ & 1 & 2 & 3 & 4 & 5 & 6 & 7 & 8 & 9 \\
\hline PJ & 4.64 & 1.24 & $(0.92)$ & & & & & & & & \\
\hline DJ & 4.14 & 1.46 & $0.38^{* * *}$ & $(0.90)$ & & & & & & & \\
\hline IJ & 4.01 & 1.19 & $0.59^{* *}$ & $0.53^{* *}$ & $(0.89)$ & & & & & & \\
\hline InJ & 4.44 & 1.14 & $0.51^{* *}$ & $0.40^{\text {** }}$ & $0.45^{* \cdot k}$ & (0.89) & & & & & \\
\hline OJ & 3.56 & 1.58 & $0.43^{* * *}$ & $0.34^{* * *}$ & $0.48^{* *}$ & $0.53^{* * *}$ & $(0.80)$ & & & & \\
\hline WGI & 3.76 & 1.26 & $0.53^{* * *}$ & $0.55^{* * *}$ & $0.34^{* * *}$ & $0.39^{\text {** }}$ & $0.41^{* * *}$ & $(0.84)$ & & & \\
\hline $\mathrm{C}$ & 3.91 & 0.86 & $0.21^{*}$ & $0.30^{* *}$ & $0.37^{* *}$ & $0.28^{*}$ & $0.37^{* * *}$ & $0.21^{* * *}$ & $(0.81)$ & & \\
\hline $\mathrm{P}$ & 3.62 & 0.95 & $0.48 *$ & $0.44 * *{ }^{* *}$ & $0.51^{* *} \stackrel{*}{*}$ & $0.42 *$ & $0.38^{* * *}$ & $0.56 * *$ & $0.37 * *$ & $(0.86)$ & \\
\hline SL & 4.48 & 0.79 & 0.26 & 0.34 & 0.21 & 0.30 & 0.31 & 0.49 & 0.32 & 0.08 & $(0.93)$ \\
\hline
\end{tabular}

Note: $\mathrm{PJ}=$ procedural justice,$\quad \mathrm{DJ}=$ distributive justice, $\quad \mathrm{InJ}=$ interactional justice, $\quad \mathrm{IJ}=$ informational $\quad$ justice, $\mathrm{WGI}=$ work group $\quad$ identification, $\quad \mathrm{C}=$ conscientiousness,

$\mathrm{P}=$ presenteeism, $\mathrm{SL}=$ social loafing.

Figures in parentheses are alpha reliabilities.

$* \mathrm{p}<0.05$.

** $\mathrm{p}<0.01$ 
which were collected from the same source (employees from same department) captured distinct constructs. Table 1 shows results of comparison models. As shown in Table 1 , CFA results showed that relative to the hypothesised seven-factor model $\left(x^{2}=266.34 ;\right.$ df $=87$; $p<0.01 ;$ TLI $=$ 0.97 ; $\mathrm{CFI}=0.96$; RMR $=0.02$; RMSEA $=0.03$ ), all the other alternative models where the indicators of two constructs were set to load on a single construct fit the data significantly worse. Factor loadings for all the seven factors also showed high significant standardized loadings $>0.65$, providing support for convergent validity. We also compared our hypothesised model to a load on to a single construct (Table 1 , model 5). Relative to the hypothesised seven-factor model, this alternative model fit the data significantly worse $\left(\mathrm{x}^{2}=1246.34\right.$; $\mathrm{df}=105$; D $\mathrm{x}^{2}[5]=$ 1601.69; $\mathrm{p}<0.01$; TLI $=0.67$; CFI $=0.69$; RMR $=0.08$; RMSEA $=0.21$ ). These results further support the discriminant validity of procedural, distributive, informational, interactional justice; overall justice and work group identification.

Next we examined a measurement model that included all of the study variables (e.g., procedural, distributive, informational and interactional justice; overall justice, work group identification, conscientiousness, presenteeism and social loafing) to assess the relationships between latent variables and their indicators. For both presenteeism and social loafing, we randomly created three parcels of items. Results showed that the ninefactor measurement model fit the data well $\left(\mathrm{x}^{2}=566.34 ; \mathrm{df}=177 ; \mathrm{p}<0.01\right.$; TLI $=0.93$; CFI $=0.99$; $\mathrm{RMR}=0.02$; RMSEA $\left.=0.04\right)$. The descriptive statistics, internal consistency reliabilities and intercorrelations of all study variables are presented in Table 2.

Hypothesis 1 predicted that all four dimensions of organisa-tional justice, i.e., procedural, distributive, informational and interactional will positively relate to overall justice. In Hypothesis 2, we posited that overall justice will positively relate to work 
group identification. We used the same parcel of items of the model above. The HLM results testing these hypotheses are shown in Fig. $2\left(\mathrm{x}^{2}=\right.$ 589.74; $\mathrm{df}=165 ; \mathrm{p}<0.001$; TLI $=0.93$; CFI $=0.93$; SRMR $=0.05$; RMSEA $=0.06$ ). We allowed the disturbance terms of work group identification and conscientiousness as well as disturbance terms of presenteeism and social loafing co-varying in order to provide a non-causal association between these variables. As shown in Fig. 1 , procedural justice $(b=0.22, p<0.001)$, distributive justice $(b=0.24, p<0.001)$, informational justice $(b=0.32, p<0.001)$ and interactional justice $(b=0.42, p<0.001)$, respectively, are all related to overall justice positively, thereby supporting Hypothesis 1 . Hypothesis 2 was also supported. The HLM results showed that overall justice positively related to work group identification $(b=0.62, \mathrm{p}<0.001)$.

Hypotheses 3a and 3b suggested that work group identification will mediate the influence of overall justice on presenteeism and social loafing respectively, whereas Hypotheses $4 \mathrm{a}$ and $4 \mathrm{~b}$ predicted that conscientiousness will influence the interaction of work group identification on presenteeism and social loafing respectively. In the first alternative model, we dropped the direct path from work group identification to presenteeism because this path was not significant as shown in Fig. $2(b=0.17, p=n . s$.). This first alternative model exhibited fit statistics almost identical to

that of Fig. $2\left(\mathrm{x}^{2}=549.34 ; \mathrm{df}=175\right.$;

$\mathrm{CFI}=0.93 ; \mathrm{SRMR}=0.05 ; \mathrm{RMSEA}=0.06)$

chi-square being non-significant $\left(\mathrm{Dx}^{2}[1]=4.02\right.$, n.s.). The second model was similar to Fig. 2 except we added two direct paths from overall justice to both presenteeism and social loafing. This second model also exhibited fit statistics similar to Fig. $2\left(\mathrm{x}^{2}=529.23\right.$;

$$
\text { df }=172 ; \quad \mathrm{p}<0.001 ; \quad \mathrm{TLI}=0.93 ; \quad \mathrm{CFI}=0.93 ; \quad \mathrm{SRMR}=0.05 \text {; }
$$

RMSEA $=0.06$, with difference in chi-square non-significant

$\left(\mathrm{Dx}^{2}[3]=0.81\right.$, n.s. $)$. Further, the direct paths from overall justice

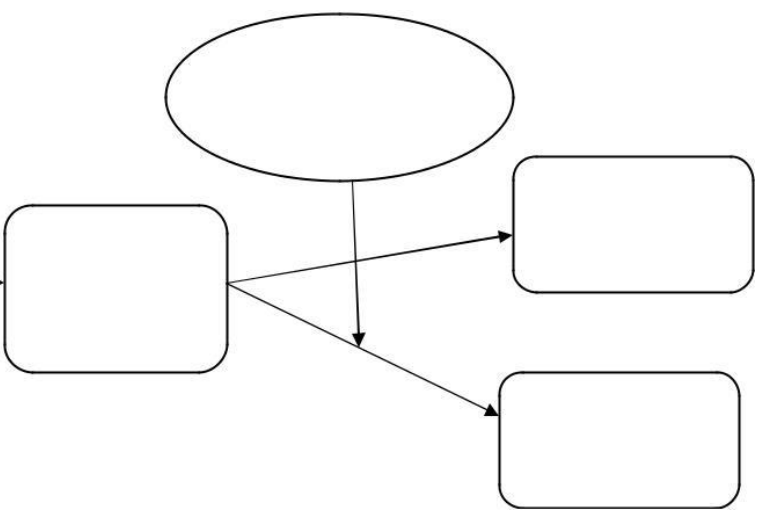




\section{Conscientiousness}

Organisational Justice:

Work

Procedural Justice

and

Distributive Justice

Justice

Group

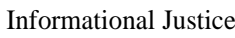

Identification

Presenteeism

Interactional Justice

Social Loafing 
Fig. 1. Hypothesised model. 


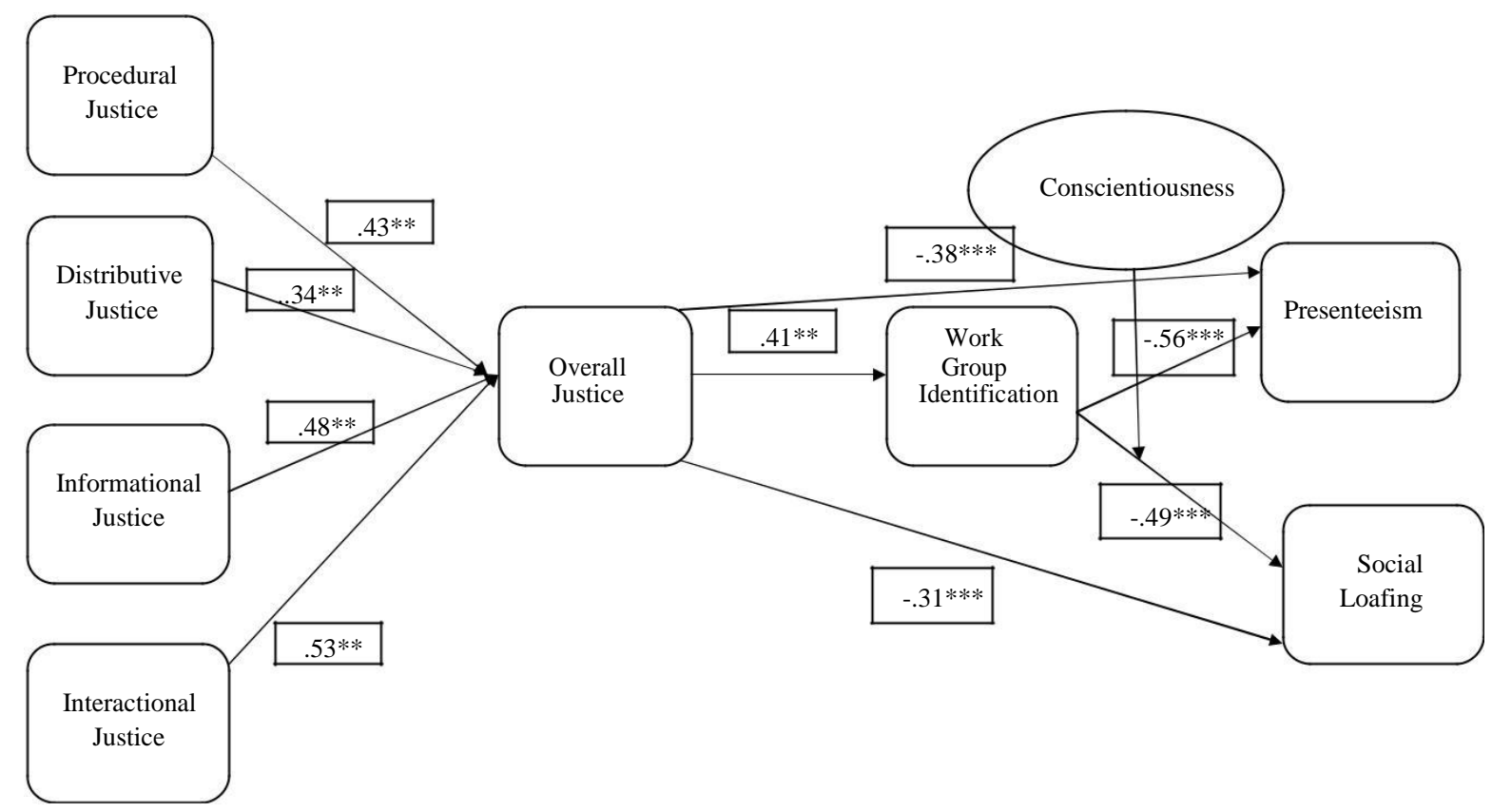

Fig. 2. Alternative model. 
to both presenteeism and social loafing and from work group identification to social loafing were not significant. Therefore, Hypothesis $3 \mathrm{~b}$ was not supported.

As a final check, we used the Preacher et al. (2007) macro to only run the moderated mediation model without organisational justice. The first part of the output is the OLS regression models for the mediator and dependent variable. These are estimated independently, unlike in an SEM context in which the coefficients would be estimated simultaneously. These are estimated inde-pendently, unlike in an SEM context in which the coefficients would be estimated simultaneously Muller, Judd, and Yzerbyt (2005). For the present model, the mediator model is a simple regression predicting the mediator variable (WGI) from the independent variable (OJ), whereas the dependent variable model is a multiple regression predicting the dependent variables (presenteeism/SL) from the mediator, the moderator (CON), the independent variable, and the interaction between the moderator and the mediator. As can be seen, the independent variable significantly predicts the mediator $($ coefficient $=$ $0.211, p<0.001$ ) in case of presenteeism and (coefficient $=0.233, p<0.001$ ) in case of social loafing. These analyses support our Hypothesis 2 , i.e., overall justice is positively related to work group identification.

The effect of the mediator on the dependent variable depends on the moderator (interaction coefficient $=0.142, p=0.019$ ). In case of presenteeism and (interaction coefficient $=0.122, \mathrm{p}=0.014$ ) in case of social loafing, our analyses supports Hypotheses $3 \mathrm{a}$ and $3 \mathrm{~b}$. Work group identification mediates the relationship between organisational justice with that of presen-teeism/social loafing (Table 3).

The last section of the output provides conditional indirect effects at increments of the moderator, as well as SEs and p-values, ranging from the lowest observed value of the moderator to the highest observed value. When they exist, the macro also inserts the upper and/or lower bounds of values of the moderator variable for which the indirect effect is statistically significant using the Johnson-Neyman technique (1936). When the indirect effect for conscientiousness $=0.086$, the $\mathrm{p}$-value for the indirect effect is 0.05 for presenteeism and when the indirect effect for conscientiousness $=0.091$, the $\mathrm{p}$-value for the indirect effect is 0.05 for social loafing. Because there is no larger value of conscientiousness 
in the output for which the p-value for the conditional indirect effect is larger than 0.05 within the range of the data, we conclude that the effect of organisational justice on presenteeism/social loafing through work group identification is statistically significant when conscientiousness is at least 1.99 for presenteeism and 1.74 for social loafing. Thus the results demonstrated that conditional indirect effects for work group identification were significant in the high conscientiousness condition (pre-senteeism $=0.086, p=0.05$; social loafing $=0.091, p=0.05$ ) but were not significant under low conscientiousness (pre-senteeism $=0.019$, n.s.; social loafing $=0.015$, n.s.). Hypotheses $4 \mathrm{a}$ and $4 \mathrm{~b}$ were therefore supported, i.e., the indirect effect of organisational justice on presenteeism and social loafing via mediator work group identification differs across levels of high and low conscientiousness. Table 4 presents moderated mediation

Table 3

Regression results for testing moderated mediation.

\begin{tabular}{|c|c|c|c|c|c|}
\hline Predictors & & \multicolumn{2}{|c|}{ Presenteeism } & \multicolumn{2}{|c|}{ Social loafing } \\
\hline \multicolumn{6}{|c|}{ Mediator variable model (predicting WGI) } \\
\hline \multicolumn{2}{|c|}{ Dependent variable model (predicting DV) } & \multicolumn{2}{|c|}{$0.211^{* * * *}$} & \multicolumn{2}{|c|}{$0.233^{* * * *}$} \\
\hline OJ & & \multicolumn{2}{|c|}{0.021} & \multicolumn{2}{|c|}{0.585} \\
\hline WGI & & \multicolumn{2}{|c|}{0.131} & \multicolumn{2}{|c|}{0.332} \\
\hline $\mathrm{CON}$ & & \multicolumn{2}{|c|}{$0.55 * *$} & \multicolumn{2}{|c|}{$0.44 * *$} \\
\hline \multicolumn{2}{|c|}{ WGI CON (interaction term) } & \multicolumn{2}{|c|}{0.142} & \multicolumn{2}{|c|}{0.122} \\
\hline & $\mathrm{CON}$ & Ind Eff & SE & $\mathrm{z}$ & $\mathrm{p}>\mathrm{jzj}$ \\
\hline \multicolumn{6}{|c|}{ Conditional indirect effects at specific value(s) of the moderator(s) } \\
\hline \multirow[t]{3}{*}{ Presenteeism } & 3.6044 & 0.1355 & 0.0320 & 4.2223 & 0.0000 \\
\hline & 4.9245 & 0.1745 & 0.0310 & 5.6298 & 0.0000 \\
\hline & 6.2446 & 0.2129 & 0.0392 & 5.4602 & 0.0000 \\
\hline \multirow[t]{3}{*}{ Social loafing } & 1.6745 & 0.2334 & 0.012 & 4.3213 & 0.0000 \\
\hline & 0.0103 & 0.7799 & 0.023 & 5.5198 & 0.0000 \\
\hline & 1.6951 & 0.6324 & 0.0272 & 5.4101 & 0.0000 \\
\hline
\end{tabular}

Note: $\mathrm{OJ}=$ organisational justice; $\mathrm{WGI}=$ work group identification, $\mathrm{CON}=$ conscien-tiousness, $\mathrm{P}=$ presenteeism, $\mathrm{SL}=$ social loafing and DV $=$ dependent variable. $\mathrm{Moderator}$ values listed are the sample mean and $1 \mathrm{SD}$.

${ }^{*} \mathrm{p}<0.05 .{ }^{* *} \mathrm{p}<0.01$

**** $\mathrm{p}<0.001$ 
Table 4

Moderated mediation results for presenteeism and social loafing across levels of conscientiousness (Hypotheses $4 a$ and $4 b$ ).

\begin{tabular}{|c|c|c|c|c|c|c|c|c|c|}
\hline \multirow[t]{2}{*}{ Moderator } & \multirow[t]{2}{*}{ Level } & \multicolumn{4}{|l|}{ Presenteeism } & \multicolumn{4}{|l|}{ Social loafing } \\
\hline & & Conditional Ind Eff & SE & $\mathrm{z}$ & $\mathrm{p}$ & Conditional Ind Eff & SE & $\mathrm{z}$ & $\mathrm{p}$ \\
\hline \multirow[t]{2}{*}{ Conscientiousness } & High & 0.086 & 0.028 & 2.61 & 0.01 & 0.091 & 0.035 & 2.78 & 0.01 \\
\hline & Low & 0.019 & 0.013 & 1.47 & 0.14 & 0.015 & 0.015 & 1.28 & 0.20 \\
\hline
\end{tabular}


results for presenteeism and social loafing across level of conscientiousness.

\section{Discussion}

Drawing on social identity theory and the group engagement model, this study proposed and examined an integrated theory of antecedents of overall justice and the mediating influence of work group identification on two CWBs - presenteeism and social loafing. Our findings revealed that organisational justice is a positive predictor of overall justice perceptions. Perhaps because the dimensions of distributive, procedural and interactional justice have been noted to contribute to the development of the overall justice perceptions (Lind, 2001), previous research on antecedents of overall justice only focused on these 3 dimensions. Two aspects of the results warrant additional attention. First, it is useful to examine further the relationship between the specific justice judgments and overall justice. In this study, all four justice facets were significant predictors of overall justice judgments. Secondly, as an exchange relationship, employees are concerned about the probability of receiving valued outcomes in exchange of their investment in this relationship. Consequently identity factors such as work group identification have a potential to undermine an employee's experience of fairness which provides the informational input into forming an overall fairness judgment. This study makes an important contribution toresearch on the group engagement model and to our understanding of the motivational implications of social identity in organisational con-texts. It does so by showing that social identity has strong associations with work group identification, and by demonstrating that social identity explains the impact of two key facets of the experiences people have with their work organisations (i.e., the organisational justice they experience and the overall justice perception they receive as a result of group membership). These findings are consistent with the group engagement model'semphasis on social identity as the primary basis of people's engagement in their groups and on the importance of locating social identity within the landscape of other factors that shape engagement.

Going beyond mere demonstration that social identity matters, the results reveal that group identity is especially critical for understanding counterproductive work behaviors, insofar as it explains the impact of two organisational conditions that have received a great deal of attention for their relation to Counterpro-ductive work behaviors: perceptions of the overall justice experi-enced at work and evaluations of the group identification received as a result of group membership. Determining that social identity provides the mechanism by which these organisational conditions relate to employee behavior provides critical insight into under-standing how, when, and why efforts to shape the context of employee work experiences may affect employee behavior. It also contributes to the growing acknowledgment within psychology that the collective self the aspect of the self most closely linked to social identity - plays a fundamental role in shaping behavior (Hogg, 2001).

\section{Managerial relevance}

These findings suggest that the basis of employees' relation-ships with their organisations is primarily linked to the role the 
organisation plays in determining how employees think and feel about themselves. Many important practical implications follow from this insight. First and foremost, our findings highlight the motivational power of getting employees to develop social identities that are grounded in their work organisations. This is critical, as the current results show that identity is central to employee behavior. Furthermore, the results indicate two impor-tant levers that organisations can use to encourage the develop-ment of social identity. First, organisations can operate in ways that employees regard as fair by instituting fair decision-making processes and extending fair quality of treatment. Second, they can provide identification outcomes that employees regard favorably and that encourage employees to link their social identities to their organisation (Blader \& Tyler, 2009).

Further, the social exchange based nature of the antecedents of overall justice that we documented, underscores the importance of organisations investing in a mutually beneficial long-term relationship with their employees. Such an investment will assure employees control over their receipt of valued job outcomes which provides the informational input into overall justice. Second, the mediating and moderating influences we uncovered provide organisations and their managers an insight into why overall justice has its demonstrated performance implications.

Aggressive competition in today's marketplace has led orga-nisations to strive to gain competitive advantage through further evaluation of their human capital. One strategy is to channel the creative potential of organisational incumbents. As the results of this research suggest, this can be done in one of two ways. First, through the analysis of some personality traits organisations seek in potential employees, we found direct evidence that an individual with a high sense of conscientiousness also possesses the most potential to promote positive change and therefore curbing counter productive work behaviours. Second, some researchers (e.g. Moon et al., 2008) suggest that in order to help identify separate facets to distinctive personality traits such as conscientiousness, one must narrow the conceptualisation of individual personality and therefore realize the benefits of employee taking charge behaviour.

\section{Limitations and future research}

Finally, we should acknowledge that our study has a number of limitations. By highlighting these limitations, we are simulta-neously mapping out directions for future research. First, although our study is rooted in social exchange paradigm, the cross-sectional nature of this study precludes an inference about the causal status of the relationships uncovered. Consequently, we urge future research to adopt a longitudinal research design in order to establish the causal status of the antecedents and outcomes of overall justice. Secondly, with the exception of the CWB measures, data on our study variables were based on self-reports. Next, recent research has suggested a multi-focus perspective to understanding overall justice judgments specific to an organisation or a focal supervisor (Holtz \& Harold, 2009). Therefore, future research should employ multi-foci perspective which will help in demonstrating the differential or common antecedents and outcomes of overall justice judgment. Also, 

although out research is one of the few to look at overall justice perceptions within a non-western setting, unlike Kim and Leung (2007), we only focused on why, but not how, overall justice is related to demonstrated outcomes.

\section{References}

Abrams, D., Ando, K., \& Hinkle, S. (1998). Psychological attachment to the group: cross-cultural differences in organizational identification and subjective norms as pre-dictors of workers' turnover intentions. Personality and Social Psychology Bulletin, 24(20): 1027-1039.

Ambrose, M. L., \& Arnaud, A. (2005). Are procedural justice and distributive justice conceptually distinct? In J. Greenberg \& J. A. Colquitt (Eds.), Handbook of organiza-tional justice (pp. 59-84). Mahwah, NJ: Erlbaum.

Ambrose, M. L., \& Schminke, M. (2009). The role of overall justice judgments in organizational justice research: A test of mediation. Journal of Applied Psychology, 94: 491-500.

Aronsson, G., Gustafsson, K., \& Dallner, M. (2000). Sick but yet at work: An empirical study of sickness presenteeism. Journal of Epidemiology Community Health, 54: 502-509.

Aryee, S., Budhwar, P. S., \& Chen, Z. X. (2002). Trust as a mediator of the relationship between organizational justice and work outcomes: Test of social exchange model. Journal of Organizational Behavior, 23: 267-285.

Avis, J. M., Kudisch, J. D., \& Fortunato, V. J. (2002). Examining the incremental validity and adverse impact of cognitive ability and conscientiousness of job performance. Journal of Business and Psychology, 17(1): 87-105.

Baron, R. M., \& Kenny, D. A. (1986). The moderator-mediator variable distinction in social psychological research: Conceptual, strategic, and statistical considerations. Journal of Personality and Social Psychology, 51: 1173-1182.

Barrick, M. R., \& Mount, M. K. (1991). The big five personality dimensions and job performance: A meta-analysis. Personnel Psychology, $44:$ 1-26.

Barrick, M. R., Stewart, G. J., Neubert, M. J., \& Mount, M. K. (1998). Relating member ability and personality to work-team processes and team effectiveness. Journal of Applied Psychology, 83: 377-391.

Batt, R., \& Appelbaum, E. (1995). Worker participation in diverse settings: Does the form affect the outcome, if so, who benefits? British Journal of Industrial Relations, 33(3): $353-378$.

Berger, M. L., Howell, R., Nicholson, S., \& Sharda, C. (2003). Investing in healthy human capital. Journal of Occupational and Environmental Medicine, 45(12): 1213-1225.

Bies, R. J., \& Moag, J. F. (1986). Interactional justice: Communication criteria of fairness. In Lewicki, R. J., Sheppard, B. H., \& Bazerman, M. H. (Eds.), Research on negotiations in organizations (1, pp. 43-55). Greenwich, CT: JAI Press.

Blader, S., \& Tyler, T. R. (2009). Testing and expanding the group engagement model. Journal of Applied Psychology, 94: 445-464.

Blau, P. (1964). Exchange and power in social life. New York: Wiley.

Carron, A., Burke, S., \& Prapavessis, H. (2004). Journal of Applied Sport Psychology, 16: 41-58.

Ceridian (2006). The lights are on; but nobody's at home: Preventing Presenteeism http:// www.ceridian.com/myceridian/connection/content/1,4268,13896-61949,00.html Accessed 20.01.07

Cohen-Charash, Y., \& Spector, P. E. (2001). The role of justice in organizations: A meta-analysis. Organizational Behavior and Human Decision Processes, 86: $278-321$.

Colquitt, J. A. (2001). On the dimensionality of organizational justice: A construct validation of a measure. Journal of Applied Psychology, 86(3): 386-400.

Colquitt, J. A., Conlon, D. E., Wesson, M. J., Porter, C. O. L., \& Ng, K. Y. (2001). Justice at the millennium: A meta-analytic review of 25 years of organizational justice research Journal of Applied Psychology, 86: 425-445.

Colquitt, J. A., Greenberg, J., \& Scott, B. A. (2005). Organizational justice: Where do we stand? In J. Greenberg \& J. A. Colquitt (Eds.), Handbook of organizational justice (pp. 589-619). Mahwah, NJ: Erlbaum.

Costa, P. T., McCrae, R. R., \& Dye, D. A. (1991). Facet scales for agreeableness and conscientiousness: A revision of the NEO personality inventory. Personality and Individual Differences, 12: 887-898.

Cropanzano, R, \& Greenberg, J. (1997). Progress in organizational justice: tunneling through the maze. In C. Cooper \& I. T. Robertson (Eds.), International review of industrial and organizational psychology (pp. 317-372). New York: John Wiley \&Sons.

Cropanzano, R., Byrne, Z. S., Bobocel, D. R., \& Rupp, D. E. (2001). Moral virtues, fairness heuristics, social entities, and other denizens of organizational justice. Journal of Vocational Behavior, 58: 164-209.

Digman, J. M. (1990). Personality structure: Emergence of the five factor model. Annual Review of Psychology, 41: 417-440.

Duffy, M. K., \& Shaw, J. D. (2000). The Salieri syndrome: Consequences of envy in groups. Small Group Research, 31: 3-23.

Earley, P. G. (1989). Social loafing and collectivism: A comparison of the United States and the People's Republic of China. Administrative Science Quarterly, 34: 565-581.

Eblen, A. L. (1987). Communication, leadership, and organizational commitment. Central States Speech Journal, 38: 181-195.

Edwards, J. R., \& Lambert, L. S. (2007). Methods for integrating moderation and mediation: A general analytical framework using moderated path analysis. Psy-chological Methods, 12: 1-22.

Erdogan, B., \& Liden, R. C. (2006). Collectivism as a moderator of responses to organizational justice: Implications for leader-member exchange and ingratiation. Journal of Organizational Behavior, 27: 1-17. 
Fornell, C., \& Larcher, D. F. (1981). Structural equation models with unobservable variables and measurement errors. Journal of Marketing Research, 18(1): 39-50.

Fox, S., Spector, P. E., \& Miles, D. (2001). Counterproductive work behavior (CWB) in response to job stressors and organizational justice: Some mediator and moderator tests for autonomy and emotions. Journal of Vocational Behavior, 59: 291-309.

Frone, M. R. (1999). Work stress and alcohol use. Alcohol Research \& Health, 23: 284- 291.

Gagne, M., \& Zuckerman, M. (1999). Performance and learning goal orientations as moderators of social loafing and social facilitation. Small Group Research, 30 : $524-541$.

George, J.M. (1992). Extrinsic and intrinsic origins of perceived social loafing in organizations. Academy of Management Journal, 35: $191-202$.

George, J. M. (1995). Asymmetrical effects of rewards and punishments: The case of social loafing. Journal of Occupational and Organizational Psychology, 68: 327-338.

Goetzel, R. Z., Long, S. R., Ozminkowski, R. J., Hawkins, K., Wang, S., \& Lynch, W. (2004). Health, absence, disability and presenteeism cost estimates of certain physical and mental health conditions affecting U.S. employers. Journal of Occupational and Environmental Medicine, 46: 398-412.

Grebner, S, Semmer, N. K., Fasco, L. L., Gut, S., Kalin, W., \& Elfering, A. (2003). Work conditions, well-being, and job related attitudes among call center agents. Euro-pean Journal of Work and Organizational Psychology, 12(4): 341-365.

Greenberg, J. (1990). Organizational justice: Yesterday, today, and tomorrow. Journal of Management, 16: 399-432.

Greenberg, J. (2001). Setting the justice agenda: Seven unanswered questions about "what, why, and how". Journal of Vocational Behavior, 58: 210-219.

Grimshaw, D., \& Rubery, J. (1998). Integrating the internal and external labour markets. Cambridge Journal of Economics, 22(2): 199-220.

Hemp, P. (2004). Presenteeism at work but out of it. Harvard Business Review. http:// www.healthyworkplace.com.au/Article2004.pdf Accessed 20.01.07.

Hofstede, G. (1980). Culture's consequences: International differences in work-related values. Newbury Park, CA: Sage.

Holtz, B. C., \& Harold, C. M. (2009). Fair today fair tomorrow? A longitudinal investi-gation of overall justice perceptions. Journal of Applied Psychology, 94: 1185-1199.

Hogg, M. A. (2001). A social identity theory of leadership. Personality and Social Psychology Review, 5(2001): 184-200.

Hough, L. M., Eaton, N. K., Dunnette, M. D., Kamp, J. D., \& McCloy, R. A. (1990). Criterion-related validities of personality constructs and the effect of response distortion on those validities. Journal of Applied Psychology, 7: 581-595.

IPIP (2001): International Personality Item Pool (2001). A scientific collaboratory for the development of advanced measures of personality traits and other individual differences. http://www.ipip.ori.org/ Retrieved 31.08.05.

James, L. R., \& Brett, J. M. (1984). Mediators, moderators, and tests for mediation. Journal of Applied Psychology, 69: 307-321.

Johnson, P. O., \& Neyman, J. (1936). Tests of certain linear hypotheses and their applications to some educational problems. Statistical Research Memoirs, 1: 57-93.

Jones, D. A., \& Martens, M. (2007). The mediating role of overall fairness and the moderating role of trust certainty in justice-criteria relationships: Testing funda-mental tenets of fairness heuristic theory. Best Paper Proceedings of the 67th Annual Meeting of the Academy of Management. Philadelphia, PA

Kanter, R. (1983). The change masters. New York: Simon \& Schuster.

Karau, S. J., \& Williams, K. D. (1994). Social loafing: A meta-analytic review and theoretical integration. Journal of Personality and Social Psychology, 65 : 681-706.

Katz, D., \& Kahn, R. L. (1978). The social psychology of organizations. New York: Wiley. Kidwell, R. E., \& Bennett, N. (1993). Employee propensity to withhold effort: A

Review, 18: 429-456

Kim, T. Y., \& Leung, K. (2007). Forming and reacting to overall organizational fairness perception: A cross-cultural comparison. Organizational Behavior and Human De-cision Processes, 104: 83-95.

Knights, D., \& McCabe, D. (1998). Life is but a dream: obliterating politics through BPR.

Human Relations, 51(6): 761-789.

Konovosky, M. A., \& Organ, D. W. (1996). Dispositional and contextual determinants of organizational citizenship behavior. Journal of Organizational Behavior, 17: 253- 266.

Konovsky, M. A. (2000). Understanding procedural justice and its impact on business organizations. Journal of Management, $26(3): 489-511$.

Konovsky, M. A., \& Pugh, S. D. (1994). Citizenship behavior and social exchange. Academy of Management Journal, 37: 656-669.

Koopman, C., Pelletier, K., Murray, J., Sharda, C., Berger, M., Turpin, R., et al. (2002). Stanford presenteeism scale: health status and employee productivity. Journal of Occupational and Environmental Medicine, 44(1): 14-20.

Latane, B., Williams, K. D., \& Harkins, S. (1979). Many hands make light the work: The causes and consequences of social loafing. Journal of Personality and Social Psychol-ogy, 37: 822-832.

Leifer, M. P., \& Maslach, C. (1988). The impact of interpersonal environment burnout and organizational commitment. Journal of Organizational Behavior, 9: 297-308.

Leventhal, G. S. (1976). The distribution of rewards and resources in groups and organizations. In Berkowitz, L., \& Walster, W. (Eds.), Advances in experimental social psychology (Vol. 9, pp. 91-131). New York: Academic Press.

Lewig, K. A., \& Dollard, M. F. (2003). Emotional dissonance, emotional exhaustion and job satisfaction in call center workers. European Journal of Work and Organizational Psychology, 12(4): 366-392.

Lewis, S., \& Cooper, C. (1996). Balancing the work family interface. A European perspective. Human Resource Management Review, 5: 289-305.

Lewis, S., \& Cooper, C. L. (1999). The work-family research agenda in changing contexts.

Journal of Occupational Health Psychology, 4: 382-393. 

Lind, E. A. (2001). Fairness heuristics theory: Justice judgments as pivotal cognitions in organizational relations. In J. Greenberg \& R. Cropanzano (Eds.), Advances in organizational justice (pp. 56-88). Stanford, CA: Stanford University Press.

Lind, E. A., \& Tyler, T. R. (1988). The social psychology of procedural justice. N.Y. Plenum. Lind, E. A., Kanfer, R., \& Earley, C. (1990). Voice, control, and procedural justice. Journal of Personality and Social Psychology, 59: 952-959.

Lipponen, J, Olkkonen, M., \& Moilanen, M. (2004). Perceived procedural justice and employee responses to an organizational merger. European Journal of Work and Organizational Psychology, 13: 391-413.

Loi, R., Ngo, H. Y., \& Foley, S. (2006). Linking employees' justice perceptions to organizational commitment and intention to leave: the mediating role of per-ceived organizational support. Journal of Occupational and Organizational Psychol-ogy, 79: 101-120.

Mael, F. A., \& Ashforth, B. E. (1992). Alumni and their alma mater. Journal of Organiza-tional Behavior, 13: 103-123.

Manogran, P., Stauffer, J., \& Conlon, E. (1994). Leader-member exchange as a key mediating variable between employees' perceptions of fairness and organizational citizenship behaviour. National Academy of management proceedings, Dallas, TX.

Masterson, S. S., Lewis, K., Goldman, B. M., \& Taylor, M. S. (2000). Integrating justice and social exchange: The differing effects of fair procedures and treatment on work relationships. Academy of Management Journal, 43: 738-748.

Miles, J. A., \& Greenberg, J. (1993). Using punishment threats to attenuate social loafing effects among swimmers. Organizational Behavior and Human Decision Processes, 56: 246-265.

Moon, H., Kamdar, D., Mayer, D. M., \& Takeuchi, R. (2008). Me or we? The role of personality and justice as other-centered antecedents to taking charge within organizations. Journal of Applied Psychology, 93: 84-94.

Moorman, R. H., Niehoff, B. P., \& Organ, D. W. (1993). Treating employees fairly and organizational citizenship behavior: Sorting the effects of job satisfaction, organi-zational commitment, and procedural justice. Employee Responsibilities and Rights Journal, 6: 209-225.

Mulholland, K. (2004). Workplace resistance in an Irish Call Center: Slamming, smok-ing and leaving. Work, Employment and Society, 18(4): 709-772.

Mullen, B. (1983). Operationalizing the effect of the group on the individual: A self-attention perspective. Journal of Experimental Social Psychology, 19: 295-322.

Muller, D., Judd, C. M., \& Yzerbyt, V. Y. (2005). When moderation is mediated and mediation is moderated. Journal of Personality and Social Psychology, 89: 852-863.

Murphy, S. M., Wayne, S. J., Liden, R. C., \& Erdogan, B. (2003). Understanding social loafing: The role of justice perceptions and exchange relationships. Human Rela-tions, 56: 61-83.

Nikolau, I., \& Robertson, I. T. (2001). The five-factor model of personality and work behaviour in Greece. European Journal of Work and Organizational Psychology, 10: 161186.

Olkkonen, M., \& Lipponen, J. (2006). Relationships between organizational justice, identification with the organization and the work-unit, and group-related out-comes. Organizational Behavior and Human Decision Processes, 100: 202-215.

Organ, D. W., \& Lingl, A. (1995). Personality, satisfaction, and organizational citizenship behavior. Journal of Social Psychology, 135: 339-350.

Organ, D. W., \& Ryan, K. (1995). A meta-analytic review of attitudinal and dispositional predictors of organizational citizenship behavior. Personnel Psychology, 48: 775- 802.

Parikh, I. J., \& Garg, P. (1990). Indian organizations: value dilemmas in managerial roles. (pp. 175-190). In A. M. Jaeger \& R. N. Kanungo (Eds.), Management in developing countries. New York: Routledge.

Pratt, M. G. (1998). To be or not to be: Central questions in organizational identification. In D. A. Whetten \& P. C. Godfrey (Eds.), Identity in organizations (pp. 171-207) Thousand Oaks, CA: Sage.

Preacher, K. J., Rucker, D. D., \& Hayes, A. F. (2007). Assessing moderated mediation hypotheses: Theory, methods, and prescriptions. Multivariate Behavioral Research, 42: $185-227$.

Price, K. H., \& Harrison, D. A. (2006). Withholding inputs in team context: Member composition, interaction process, evaluation structure, and social loafing. Journal of Applied Psychology 91(6.)

Richter, A., West, M. A., Van Dick, R., \& Dawson, J. F. (2006). Boundary spanners' identification: Intergroup contact and effective intergroup relations. Academy of Management Journal, 49: 1252-1269.

Robertson, I. T., \& Callinan, M. (1998). Personality and work behaviour. European Journal of Work and Organizational Psychology, 7: 321-340.

Roch, S. G., \& Shanock, L. R. (2006). Organizational justice in an exchange framework: Clarifying organizational justice distinctions. Journal of Management, 32: $299-322$.

Rose, E., \& Wright, G. (2005). Satisfaction and dimensions of control among call center customer service representatives. International Journal of Human Resource Management, 16(1): 136-152.

Rousseau, D. M. (1998). Why workers still identify with organizations. Journal of Organizational Behavior, 19: 217-233. 
Rubery, J., Carroll, M., Cooke, F. L., Grugulis, I., \& Earnshaw, J. (2004). Human resource management and the permeable organization: The case of the multi-client call center. The Journal of Management Studies, 41(7): 1199-1221.

Schneider, F. W., \& Delaney, J. G. (1972). Effect of individual achievement motivation on group problem solving efficiency. Journal of Social Psychology, 86: 291-298.

Shapiro, D. (2001). The death of justice theory is likely if theorists neglect the "wheels" already invented and the voices of the injustice victims. Journal of Vocational Behavior, 58: $235-242$.

Simpson, R. (1998). Organizational restructuring and presenteeism: The impact of long hours on the working lines of managers in the UK. Management Research News, 21: 19.

Skarlicki, D. P., \& Folger, R. (1997). Retaliation in the workplace: The roles of distribu-tive, procedural, and interactional justice. Journal of Applied Psychology, 82: $434-443$.

Skarlicki, D., Folger, R., \& Tesluk, P. (1999). Personality as a moderator in the relation-ship between fairness and retaliation. The Academy of Management Journal, 42: 100-110.

Stewart, W., Matousek, D., \& Verdon, C. (2003). The American productivity audit and the campaign for work and health. Hunt Valley, MD: The Center for Work and Health, Advanced PCS.

Tajfel, H., \& Turner, J. C. (1979). An integrative theory of intergroup conflict. In W. Austin \& S. Worchel (Eds.), The social psychology of intergroup relations (pp. 33-47). Monterey, CA: Brooks.

Taylor, P., Mulvey, G., Hyman, J., \& Bain, B. (2002). Work organization, control and the experience of work in call centers. Work, Employment and Society, 16(1): 133-150.

Thibaut, J., \& Walker, L. (1975). Procedural justice: A psychological analysis. Hillsdale, NJ: Erlbaum.

Tornblom, K. Y., \& Vermunt, R. (1999). An integrative perspective on social justice: Distributive and procedural fairness evaluations of positive and negative outcome allocations. Social Justice Research, 12: 39-64.

Tripathi, R. C. (1990). Interplay of values in the functioning of Indian organizations. International Journal of Psychology, 25: 715-734.

Tyler, T. R. (1999). Why people cooperate with organizations: An identity-based perspective. Research in Organizational Behavior, 21: $201-246$.

Tyler, T. R., \& Blader, S. L. (2000). Cooperation in groups: Procedural justice, social identity and behavioral engagement. Philadelphia: Psychology Press.

Tyler, T. R., \& Blader, S. L. (2001). Identity and cooperative behavior in groups. Group Processes and Intergroup Relations, 4: $207-226$.

Tyler, T. R., \& Blader, S. L. (2003). Cooperation in groups: Procedural justice, social identity and behavioral engagement. Philadelphia: Psychology Press.

Tyler, T. R., \& Caine, A. (1981). The role of distributional and procedural fairness in the endorsement of formal leaders. Journal of Personality and Social Psychology, 41: 642655

Tyler, T. R., \& Smith, H. J. (1997). Social justice and social movements. In D. Gilbert, S. Fiske, \& G. Lindzey (Eds.), Handbook of Social Psychology (4th ed.). New York: McGraw-Hill.

Tyler, T. R., Degoey, P., \& Smith, H. (1996). Understanding why the justice of group procedures matters: A test of the psychological dynamics of the group-value model. Journal of Personality and Social Psychology, 70: 913-930.

Van Dick, R., Wagner, U., Stellmacher, J., \& Christ, O. (2004). The utility of a broader conceptualization of organizational identification: Which aspects really matter? Journal of Occupational and Organizational Psychology, 77: 171-191.

Van Knippenberg, D., \& Sleebos, E. (2001). Further exploration of the organizational identification concept: Identification versus commitment. University of Amster-dam. Unpublished manuscript.

Van Knippenberg, D., \& Sleebos, E. (2006). Organizational identification versus organi-zational commitment: self-definition, social exchange, and job attitudes. Journal of Organizational Behavior, 27(5): 571-584.

Van Knippenberg, D, \& Van Schie, C. M. (2000). Foci and correlates of organizational identification. Journal of Occupational \& Organizational Psychology, 73 (2): 137-147.

Walumbwa, F. O., Cropanzano, R., \& Hartnell, C. A. (2009). Organizational justice, voluntary learning behavior, and job performance. A test of the mediating effects of identification and leader-member exchange. Journal of Organizational Behavior, 30: 1103-1126.

Wang, P. S., Beck, A., Berglund, P., Leutzinger, J. A., Pronk, N., Richling, D., et al. (2003). Chronic medical conditions and work performance in the health and work performance questionnaire calibration surveys. Journal of Occupational and Environmen-tal Medicine, 45(12): 1303-1311.

Witt, L. A., Andrews, M. C., \& Carlson, D. S. (2004). 'When conscientiousness' isn't enough: Emotional exhaustion and performance among call center customer service representatives. Journal of Management, 30(1): 149.

Worrall, L., \& Cooper, C. L. (2002). The impact of organizational change on the experiences and perceptions of UK managers from 1997-2000. Working Paper Series, University of Wolver Hampton.

Zengerle, J. (2004, December 12). The fourth annual year in ideas. New York Times Magazine (pp. 49-103). 